Accepted Date : 09 - 06-2021, Publish Date : 16-06-2021 Vol 01. Issue 01

\title{
Application Design For Office Stationary Inventory Management Based On Vb.Net At PT. Hunu Osias Padmada Eara Karawang
}

\author{
Yeny Rostiani $^{\mathrm{a} *}$ Indaryono $^{\mathrm{b}}$, Ratna Furi Handayani ${ }^{\mathrm{c}}$ \\ a,b,cSTMIK Rosma, Jl. Kertabumi No. 62, Karawang 41311, Indonesia \\ *Correspending author: yeny@rosma.ac.id
}

\begin{abstract}
The availability of office stationery is very important to make the required work smooth. In order for ATK management to be handled properly, an application is needed to manage ATK inventory data using a technology-based information system so that it becomes a complete information system. The research method used in this research is the System Development Life Cycle (SDLC). Meanwhile, the model used is the Waterfall model which starts from the specification of user requirements, planning, modeling, and coding. The procedures carried out at the user requirements specification stage include interviews, observations, literature studies, and documentation studies. At the planning stage, the steps taken are to make the tasks to be carried out including the risks that may occur and the work schedule. Furthermore, in the modeling activities carried out are the design of flow documents, DFD, data dictionary, and ERD. The last stage is coding, the steps taken are designing the program using the VB.Net programming language with SQL Server 2008 database and testing the application using black box testing, namely this test is intended to determine whether the functions, inputs and outputs of the software are in accordance with required specifications. The result of this research is the application of ATK inventory management at PT. Hunu Osias Padmada Eara Karawang which is expected to facilitate reporting and recording so that errors do not occur, and can be useful for the company in its operations in the future.
\end{abstract}

Keywords : ATK; Pengelolaan; Persediaan; SQL Server; VB.Net

\section{Abstrak}

Ketersediaaan alat tulis kantor merupakan hal yang sangat penting untuk membuat kelancaran pekerjaan yang dibutuhkan. Agar pengelolaan ATK tertangani dengan baik dibutuhkan aplikasi untuk mengelola data persediaan ATK dengan menggunakan sistem informasi berbasis teknonogi sehingga menjadi suatu sistem informasi yang lengkap. Metode penelitian yang digunakan dalam penelitian ini adalah System Development Life Cycle (SDLC). Sedangkan, model yang digunakan adalah model Waterfall yang dimulai dari spesifikasi kebutuhan pengguna, perencanaan, permodelan, dan pengkodean. Prosedur yang dilakukan pada tahap spesifikasi kebutuhan pengguna meliputi wawancara, observasi, studi kepustakaan, dan studi dokumentasi. Pada tahap perencanaan, tahapan yang dilakukan adalah membuat tugas-tugas yang akan dilakukan mencakup resiko yang mungkin terjadi dan jadwal pengerjaan. Selanjutnya, pada permodelan kegiatan yang dilakukan adalah perancangan flow document, DFD, kamus data, dan ERD. Tahap terakhir adalah pengkodean, tahapan yang dilakukan adalah merancang program dengan bahasa pemrograman VB.Net dengan Database SQL Server 2008 dan pengujian aplikasi menggunakan black box testing, yaitu Pengujian ini dimaksudkan untuk mengetahui apakah fungsi-fungsi, masukan dan keluaran dari perangkat lunak telah sesuai dengan spesifikasi yang dibutuhkan. Hasil penelitian ini adalah aplikasi pengelolaan persediaan ATK pada PT. Hunu Osias Padmada Eara Karawang yang diharapkan dapat mempermudah dalam pelaporan maupun pencatatan agar tidak terjadi kesalahan, serta dapat bermanfaat bagi perusahaan dalam operasionalnya di masa yang akan datang.

Kata Kunci : ATK; Inventory; Management; SQL Server; VB.Net 


\section{Pendahuluan}

Perkembangan Teknologi informasi dalam era globalisasi saat ini, membawa dampak positif pada dunia bisnis dalam menjalankan aktivitas usahanya, seperti dalam mengolah, memproses, menyusun maupun menyimpan data dapat dilakukan dengan menggunakan teknologi informasi. Pemanfaatan teknologi saat ini sudah menjadi kebutuhan penting dalam operasional perusahaan karena dapat mengubah proses manual menjadi otomatis, sehingga dapat meningkatkan kecepatan dalam merespon apa yang dibutuhkan.

Untuk itu agar perusahaan dapat mempertahankan kelangsungan usahanya, dan tetap optimal dalam melayani kebutuhan konsumen, diperlukan pengelolaan manajemen yang baik dan juga ketersediaan perlengkapan pekerjaan salah satunya barang habis pakai/alat tulis kantor (ATK). Menurut [1] barang habis pakai yaitu barang atau benda kantor yang penggunaannya hanya satu atau beberapa kali pakai atau tidak tahan lama, oleh karena itu agar kegiatan pemenuhan barang habis pakai yang diperlukan dapat berjalan dengan baik maka perlu adanya kegiatan pengelolaan barang habis pakai secara teratur, terperinci serta berjalan dengan baik sesuai dengan peraturan yang ada. Suatu kantor dalam melakukan aktivitasnya tidak lepas dari alat tulis kantor, karena alat tulis kantor merupakan salah satu penunjang kinerja karyawan.

Ketersediaaan ATK merupakan hal yang sangat penting untuk menunjang kelancaran pekerjaan, untuk itu dibutuhkan pengelolaan persediaan ATK yang baik, agar menghasilkan persediaan yang optimal dengan tujuan perusahaan dapat melakukan penghematan pada persediaan tersebut, karena persediaan yang terlalu banyak ataupun sedikit akan berpengaruh terhadap kinerja perusahaan.

PT Hunu Osias Padmada Eara Karawang merupakan perusahaan jasa yang bergerak di bidang jasa konsultan keuangan dan pajak yang merupakan bagian dari Grup Focus Konsultan dan berdiri sejak tahun 2008. Perusahaan ini dibentuk untuk memenuhi kebutuhan perusahaan-perusahaan dalam proses penyusunan laporan keuangan, laporan perpajakan baik memberikan pembimbingan, melakukan kontrol, konsultasi, maupun analisa. Untuk menunjang proses bisnis tersebut PT Hunu Osias Padmada Eara Karawang salah satunya membutuhkan ketersediaan alat-alat tulis kantor (ATK), untuk membantu berjalannya operasional perusahaan agar pekerjaan tidak terhambat, maka bagian persediaan yang mengelola kebutuhan bahan habis pakai ini, harus melakukan pengelolaan persediaan yang optimal, baik pencatatannya maupun kontrol persediaan agar terjadi kekurangan stok. Saat ini dalam mengelola data persediaan ATK sudah ditangani dengan baik, hanya masih menggunakan Microsoft Excel yang rentan adanya kerusakan data dikarenakan tidak adanya database. Untuk

Beberapa penelitian terdahulu seperti yang dikemukakan oleh [2] dan [3] mengungkapkan bahwa aplikasi pengendalian persediaan membantu meningkatkan efektifitas dan efisiensi suatu perusahaan dalam mengelola persediaan barang. Untuk itu agar mempermudah dalam pelaporan maupun pencatatan agar tidak terjadi kesalahan, maka perlu dirancang suatu aplikasi pengelolaan persediaan yang dibangun menggunakan Microsoft Visual Basic. Net dengan Microsoft SQL Server sebagai tempat penyimpanan datanya. Metode pengembangan sistem yang digunakan dalam penelitian ini adalah System Development Life Cycle (SDLC) waterfall. Menurut Sutabri, Waterfall adalah struktur pengembangan sistem dimana setiap tahap harus diteruskan ke tahap berikutnya untuk menghindari terjadinya pengulangan tahapan [4]. Aplikasi ini dibangun dengan tujuan untuk mempermudah antar fungsi-fungsi terkait dalam perusahaan, untuk mengelola data persediaan alat tulis kantor dengan menggunakan sistem informasi berbasis teknonogi sehingga menjadi suatu sistem informasi yang lengkap pada PT PT Hunu Osias Padmada Eara Karawang.

\section{Tinjauan Pustaka}

\subsection{Pengelolaan}

Pengelolaan adalah suatu rangkaian kegiatan perencanaan, pengorganisasian, pengarahan dan pengendalian sampai dengan pengawasan yang bertujuan untuk menggali dan memanfaatkan sumber daya alam yang dimiliki secara lancar, efektif dan efisien untuk mencapai tujuan organisasi yang telah ditetapkan sebelumnya [5].

Pengelolaan yaitu rangkaian kegiatan, pekerjaan ataupun usaha yang dilakukan oleh suatu kelompok untuk melakukan pekerjaan sampai dengan selesai untuk mencapai tujuan [6]. 


\subsection{Persediaan}

Persediaan adalah bahan atau barang yang disimpan yang akan digunakan untuk memenuhi tujuan tertentu [7]. Persediaan merupakan bagian utama dari modal kerja, sebab dilihat dari jumlahnya biasanya persediaan inilah unsur modal kerja yang paling besar. Hal ini dapat dipahami karena persediaan merupakan faktor penting dalam menentukan kelancaran operasi perusahaan. perusahaan jasa mempunyai persediaan yang habis dipakai, termasuk di dalamnya karbon, kertas, stempel, tinta, materai, dan persediaan lainnya yang berhubungan dengan perusahaan jasa [8].

\subsection{Barang Habis Pakai}

Barang habis pakai yaitu barang atau benda kantor yang penggunaannya hanya satu atau beberapa kali pakai atau tidak tahan lama. Oleh karena itu agar kegiatan pemenuhan barang habis pakai yang diperlukan dapat berjalan dengan baik maka perlu adanya kegiatan pengelolaan barang habis pakai secara teratur, terperinci serta berjalan dengan baik sesuai dengan peraturan yang ada. Suatu kantor dalam melakukan aktivitasnya tidak lepas dari alat tulis kantor. Tanpa adanya alat tulis kantor yang memadai tidak mungkin ada kinerja perkantoran yang baik. Sementara itu, untuk mengelola alat tulis kantor secara efektif diperlukan kegiatan untuk melakukan pendataan, pencatatan, dan pelaporan hasil pendataan barang [9].

Alat Tulis Kantor merupakan benda-benda yang bersifat habis-pakai untuk pelaksanaan kegiatan kantor sehari-hari oleh karyawan. Yang tergolong Office Supplier misalnya adalah pulpen, pensil, tinta, kertas, dan lain sebagainya. Supplies atau biasa disebut peralatan merupakan persediaan yang dibutuhkan oleh suatu organisasi yang pada umumnya berbentuk benda-benda atau bersifat material [10]. Alat Tulis Kantor (ATK) adalah dokumen yang sedang pada tahap pengawasan dan pengamanan dokumen serta arsip baik dalam bentuk kertas atau elektronik [11]. Alat tulis kantor dalam jurnalnya adalah benda-benda yang dipakai habis dalam pelaksanaan dalam pekerjaan sehari-hari dari pegawai pegawai tata usaha.[12]. Berikut prosedur pengelolaan barang habis kantor [11], terdiri dari:

a. Perencanaan kebutuhan dan penganggaran, dengan memperhatikan hal-hal yang meliputi: barang yang dibutuhkan, berapa biaya yang dibutuhkan, siapa yang akan mengurus dan menggunakan, alasan kebutuhan.

b. Pengadaan pada tahap ini harus memperhatikan jumlah stok barang untuk mempermudah berapa banyak barang yang dibutuhkan dalam pengadaan barang habis pakai khususnya alat tulis kantor (ATK) selanjutnya, apakah alat tulis kantor tersebut memerlukan penambahan jumlah barangnya atau tidak. Dalam hal ini pengadaan barang habis pakai khususnya alat tulis kantor (ATK) bersifat fleksibel yaitu pengadaan barangnya disesuaikan dengan kebutuhan, apabila barang yang dibutuhkan masih ada dan sesuai dengan pemenuhan kebutuhan maka tidak ada penambahan stok untuk barang tersebut. Namun apabila barang yang dibutuhkan stoknya telah habis, maka diperlukan penambahan stok untuk barang yang dibutuhkan tersebut.

c. Tahap Penerimaan merupakan bentuk tindak lanjut dari hasil pengadaan.

d. Penyimpanan barang yang sudah diterima diteliti kembali apakah jenis barang, jumlah barang sudah sesuai dengan yang ada didalam buku penerimaan barang. Apabila barang tersebut sudah sesuai dengan buku penerimaan maka akan disimpan ke tempat penyimpanan barang yang sudah disediakan.

e. Penyaluran, tahap pendistribusian barang sesuai permohonan unit kerja.

\section{Metode}

Metode yang digunakan yaitu metode pengembangan sistem model System Development Life Cycle (SDLC) Waterfall (air terjun). Menurut Pressman (2015) [13] Model Waterfall merupakan model SDLC yang menawarkan pembuatan perangkat lunak secara lebih nyata dengan beberapa tahapan diantaranya spesifikasi kebutuhan pengguna, perencanaan, permodelan, konstruksi, dan deployment. Namun, pada penelitian ini, penulis hanya menggukan empat tahap, ya Untuk lebih jelasnya terdapat pada Gambar 1. 


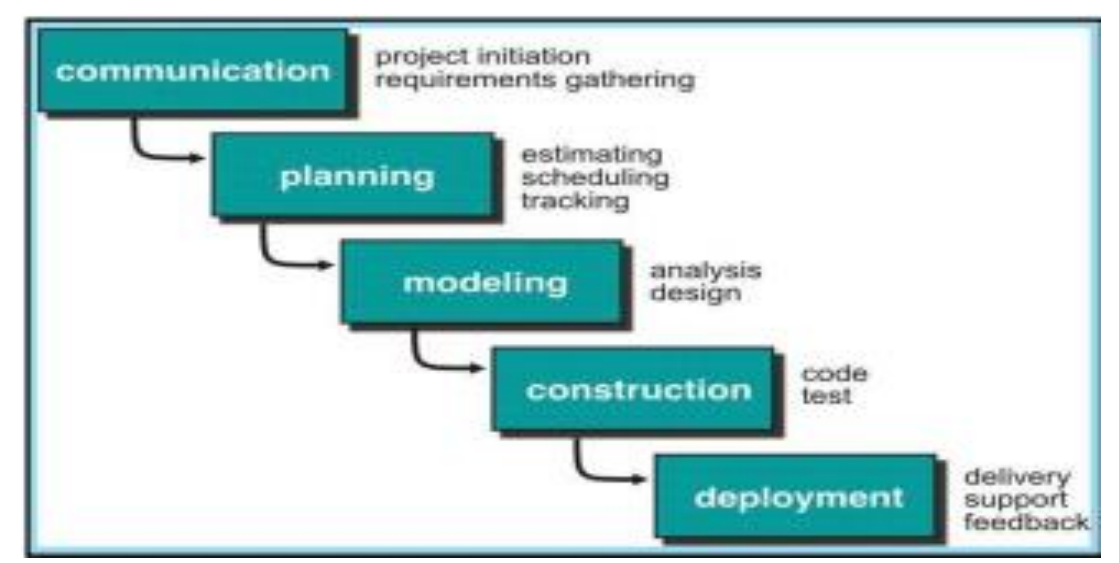

Gambar 1. System Development Life Cycle (SDLC) Waterfall

Sumber: Pressman (2015) [13]

Berikut penjelasan dari tahap-tahap model Waterfall menurut Pressman (2015) [13] yaitu:

\section{a. Communication}

Langkah pertama diawali dengan komunikasi kepada pengguna, Pada tahap ini kegiatan yang dilakukan adalah mengumpulkan data-data yang dibutuhkan dalam penelitian ini melalui :

1) Observasi, yaitu pengamatan secara langsung kegiatan yang terjadi untuk mengetahui gambaran umum mengenai perusahaan, alur kerja dan sistem yang diterapkan.

2) Wawancara, dilakukan langsung dengan karyawan bagian pengelolaan persediaan alat tulis kantor. Tujuannya yaitu untuk memperoleh gambaran, keterangan, dan penjelasan mengenai pengelolaan persediaan alat tulis kantor untuk membantu dalam penelitian ini.

3) Studi Pustaka, tahap ini digunakan penulis untuk mencari sumber referensi dari buku, jurnal ilmiah, dan dokumen yang berkaitan dengan masalah yang diteliti untuk memperoleh teori-teori dasar dan untuk membangun aplikasi tersebut.

4) Studi dokumentasi, salah satu metode pengumpulan data kualitatif dengan melihat atau menganalisis dokumen-dokumen.

\section{b. Planning}

Pada tahap ini merencanakan pengerjaan software yang akan dibangun. Planning maliputi tugas-tugas yang akan dilakukan mencakup resiko yang mungkin terjadi, hasil yang akan dibuat, dan jadwal pengerjaan.

c. Modeling

Tahap menterjemahkan syarat kebutuhan sistem ke sebuah perancangan perangkat lunak yang dapat diperkirakan sebelum dibuat coding. Tahap ini berfokus pada perancangan struktur data, arsitektur software, dan representasi interface. Metode perancangan yang akan digunakan oleh penulis dalam menyusun Tugas Akhir ini adalah perancangan flow document, perancangan data flow diagram, perancangan kamus data, dan perancangan entity relationship diagram. Tahap ini mentranslasi kebutuhan desain agar dapat diimplementasi menjadi program pada tahap selanjutnya.

d. Construction

Construction merupakan proses membuat kode (code generation). Coding atau pengkodean merupakan penerjemahan desain dalam bahasa yang bisa dikenali oleh komputer. Programmer akan menerjemahkan transaksi yang diminta oleh pengguna. Tahapan inilah yang merupakan tahapan secara nyata dalam mengerjakan suatu software, artinya pengguna komputer akan dimaksimalkan dalam tahapan ini. Setelah pengkodean selesai maka akan dilakukan testing terhadap sistem yang telah dibuat.. Tujuan testing adalah menemukan kesalahan-kesalahan terhadap sistem tersebut untuk kemudian bisa diperbaiki. Pengujian aplikasi yang akan digunakan yaitu black box testing.

\section{Hasil dan Pembahasan}

\subsection{Communicatipn (Hasil Pengumpulan Data) \\ 4.1.1. Flowchart Of Dokument Sistem yang Sedang Berjalan}


Adapun Flow of document prosedur pengelolaan persediaan Alat Tulis Kantor (ATK) pada PT Hunu Osias Padmada Eara Karawang.

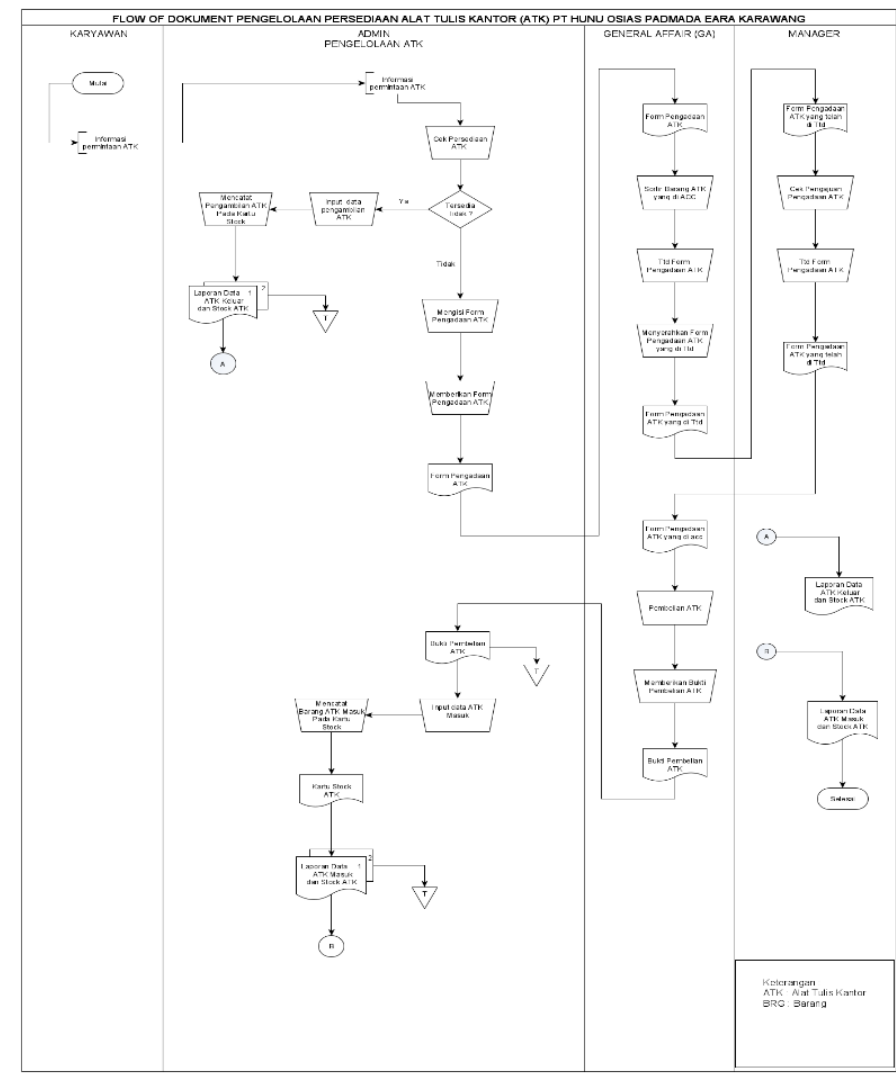

Gambar 2. Flow Of Document yang berjalan

a. Prosedur Pengadaan Barang

1) Bagian Pengelola ATK mengajukan ke kepala Bagian umum (General Affair) untuk pengajuan persediaan ATK apabila stok sudah minim. Kepala Bagian umum menyortir daftar ATK yang diajukan dari bagian pengelola ATK sebelum disetujui.

2) Kepala Bagian umum melaporkan dan meminta persetujuan kepada Manajer. Manajer memeriksa dan menyetujui pengajuan list ATK untuk dilakukan pembelian.

3) Kemudian dibuat Surat Perintah untuk melakukan pembelian ATK.

4) Setelah barang sudah dibeli, Struk diserahkan kepada Manajer sebagai bukti pembelian barang, dan barang yang telah dibeli diserahkan kepada bagian pengelola persediaan ATK.

b. Prosedur Penerimaan Alat Tulis Kantor (ATK)

1) Pengelola Persediaan ATK menerima dan mencatat dalam kartu stok dan menginput ke komputer.

2) Kemudian menyimpan ATK sesuai tempat penyimpanan masing-masing ATK.

c. Prosedur Pengeluaran Barang Alat Tulis Kantor (ATK)

1) Karyawan yang membutuhkan ATK untuk keperluan kerjanya mengisi formulir pengajuan ATK (Kartu stok ATK).

2) Formulir akan diserahkan ke bagian ATK.

3) Bagian ATK menginput pengeluaran barang ATK.

\subsubsection{Prosedur Kerja Sistem (Flow System) yang Diusulkan}

Berikut Bagan Alur Dokumen dari sistem yang diusulkan yaitu sebagai berikut: 


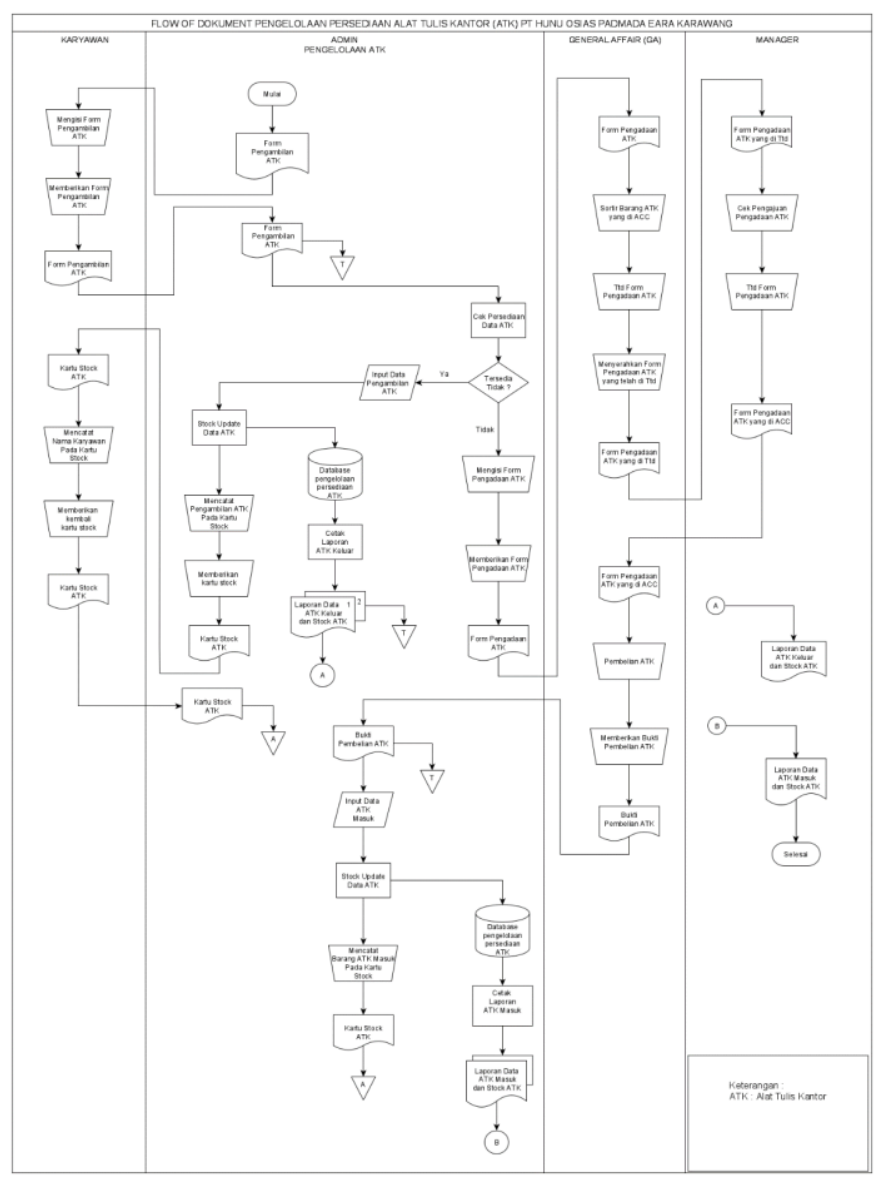

Gambar 3. Flow Of Document Sistem Usulan

a. Prosedur Pengadaan Barang

1) Bagian Pengelola ATK mengecek, mencatat dan mencocokan data fisik ATK dengan data stok barang yang minim pada sistem kemudian melakukan pengajuan pengadaan barang ke kepala Bagian umum (General Affair) dengan mengisi form pengajuan barang ATK.

2) Kepala Bagian umum menyortir daftar ATK yang diajukan dari bagian pengelola ATK sebelum disetujui.

3) Kepala Bagian umum melaporkan dan meminta persetujuan kepada Manajer. Manajer memeriksa dan menyetujui pengajuan list ATK untuk dilakukan pembelian.

4) Setelah barang sudah dibeli, Struk diserahkan kepada Pengelola ATK untuk diarsipkan sebagai bukti pembelian barang, dan barang yang telah dibeli diserahkan kepada bagian pengelola persediaan ATK. Kemudian laporan beserta bukti2 pengeluaran diserahkan kepada manajer.

b. Prosedur Penerimaan Alat Tulis Kantor (ATK)

1) Pengelola Persediaan ATK menerima, mencocokan barang ATK dengan struk dan mencatat dalam kartu stok dan menginput ke komputer.

2) Kemudian menyimpan ATK sesuai tempat penyimpanan masing-masing ATK.

c. Prosedur Pengeluaran Barang Alat Tulis Kantor (ATK)

1) Karyawan yang membutuhkan ATK untuk keperluan kerjanya mengisi formulir pengajuan ATK (Kartu Stok ATK).

2) Formulir akan diserahkan ke bagian pengelolaan ATK.

3) Bagian ATK mengecek stok barang dan menginput pengeluaran barang ATK.

4) Barang ATK diserahkan kepada karyawan yang melakukan permintaan barang ATK.

\subsubsection{Diagram Konteks}


Perancangan proses terdiri dari $D F D$ bertujuan memberikan gambaran pada sistem analisa pembuatan program mengenai masukan (input) ke dalam proses dan apa yang akan dihasilkan (output).

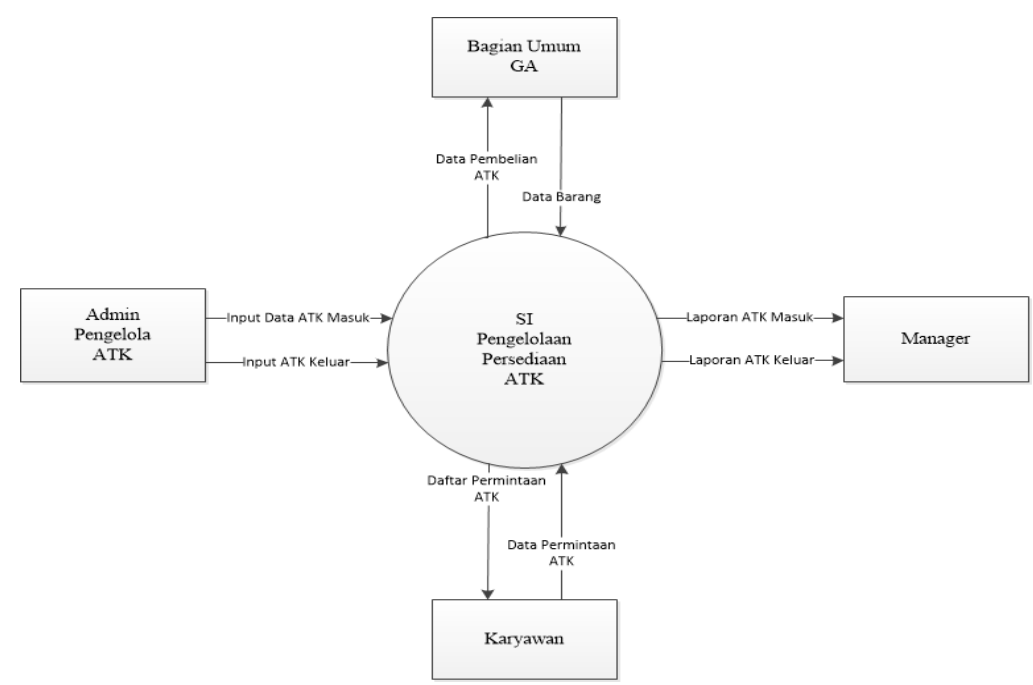

Gambar 4. Diagram Konteks

\subsubsection{Diagram Overview}

Berdasarkan analisa proses pengelolaan persediaan alat tulis kantor (ATK) pada PT Hunu Osias Padmada Eara karawang terdapat tiga proses pengelolaan persediaan ATK. Masing-masing proses diuraikan dalam diagram overview dapat dilihat pada gambar 5.

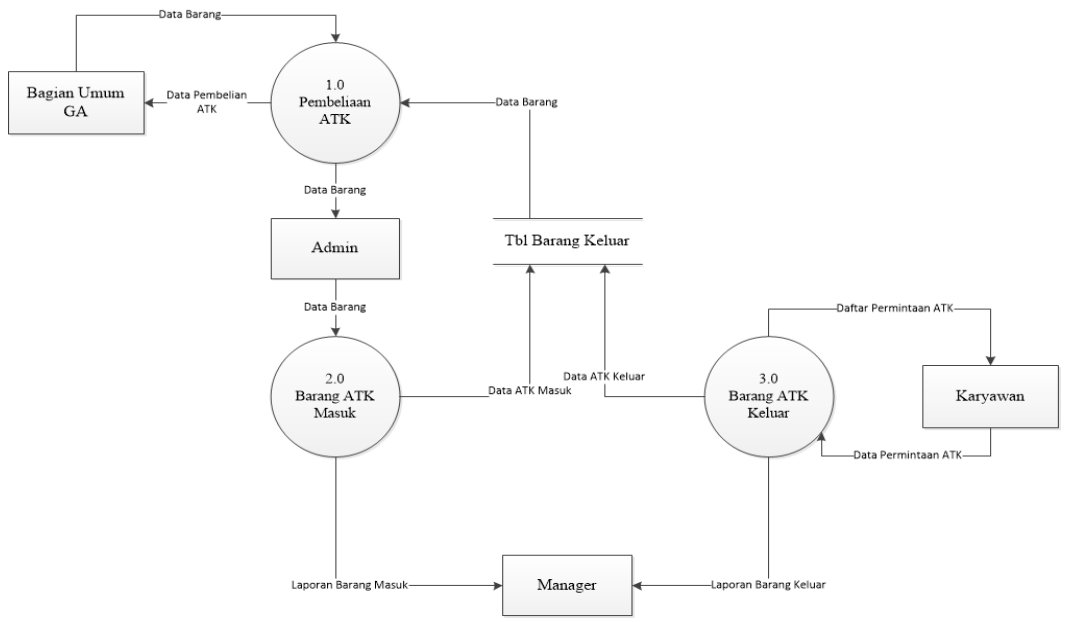

Gambar 5. Diagram Overview

\subsubsection{Diagram Rinci}

Untuk mendapatkan gambaran lebih detail pada masing-masing proses diagram overview, prosesproses tersebut selanjutnya diuraikan dalam tiga diagram rinci : diagram rinci proses 1.0 pengadaan barang ATK pada gambar 6, diagram rinci proses 2.0 barang ATK masuk pada gambar 7 dan diagram rici proses 3.0 barang ATK keluar pada gambar 8 . 


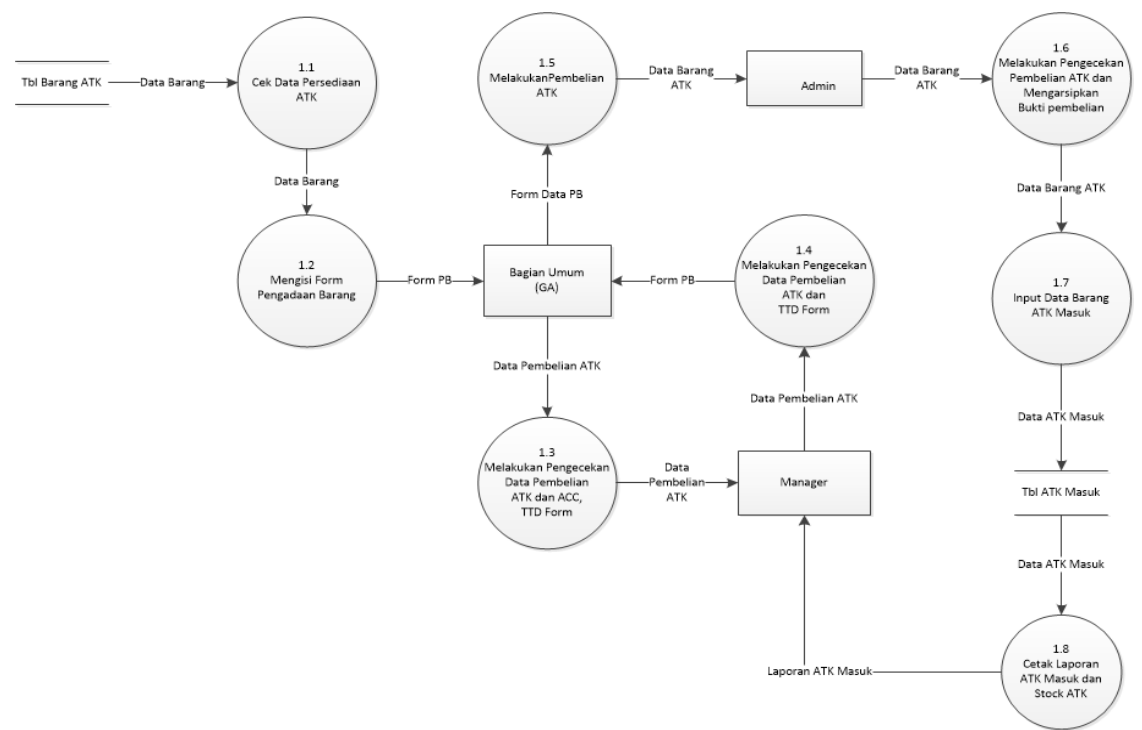

Gambar 6. Data Flow Diagram Pengadaan Barang ATK

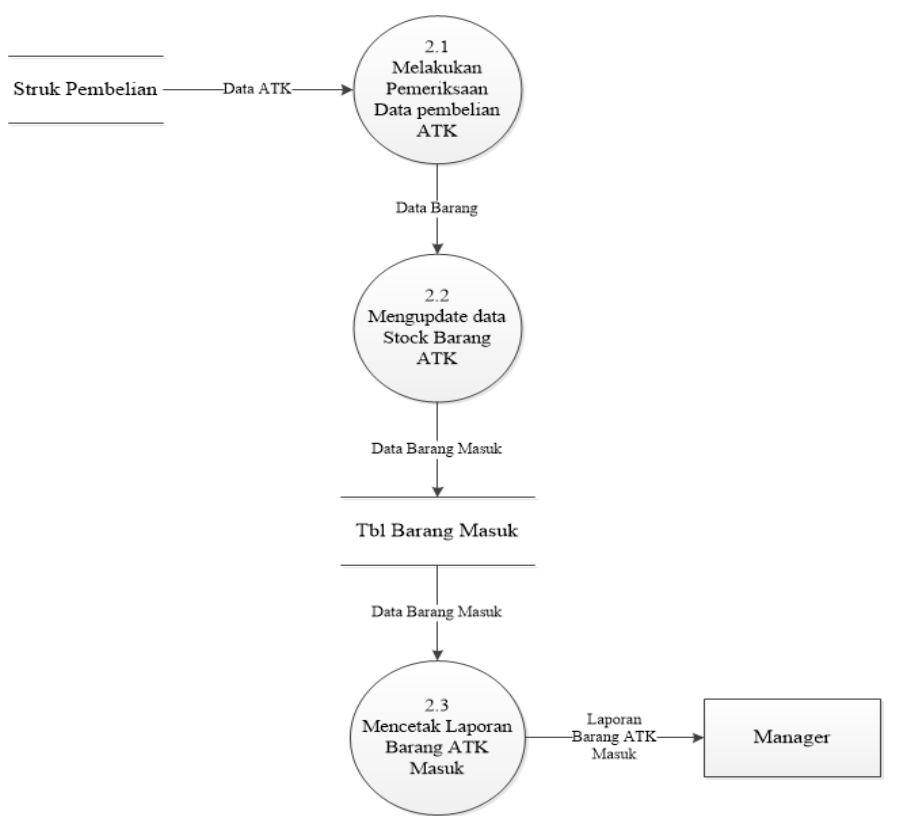

Gambar 7. Data Flow Diagram Barang ATK

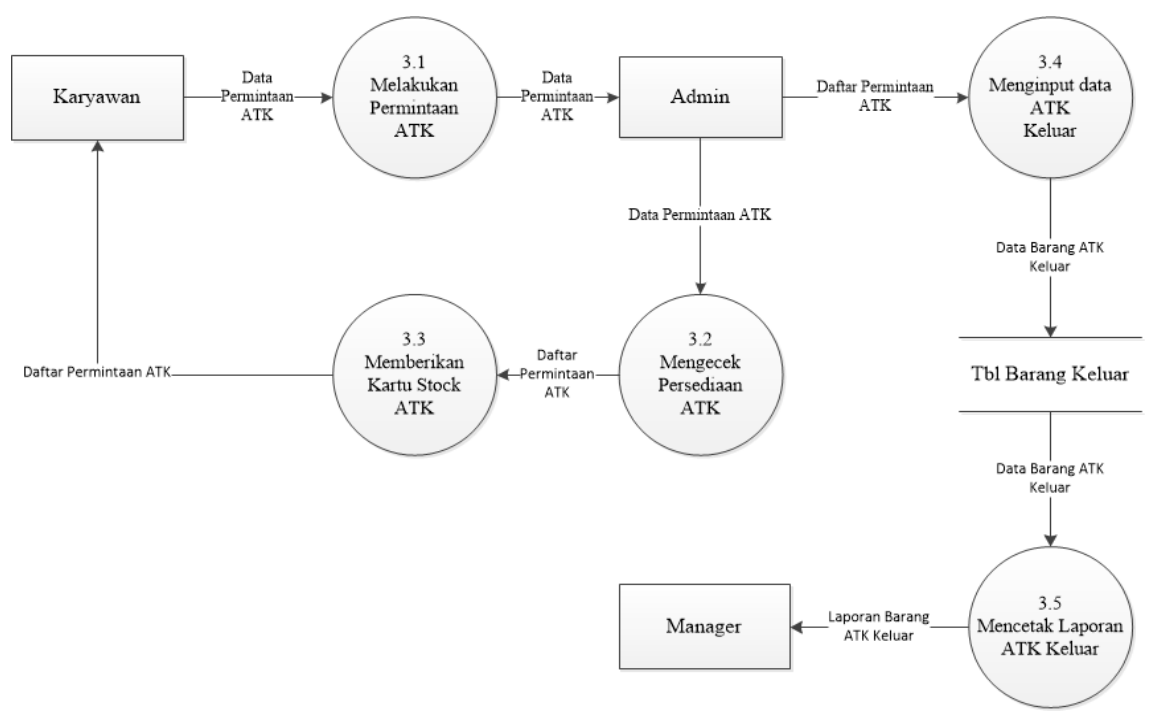

Gambar 8. Data Flow Diagram Barang ATK Keluar 


\subsection{Modelling Sistem}

\subsubsection{Form Halaman Menu Utama}

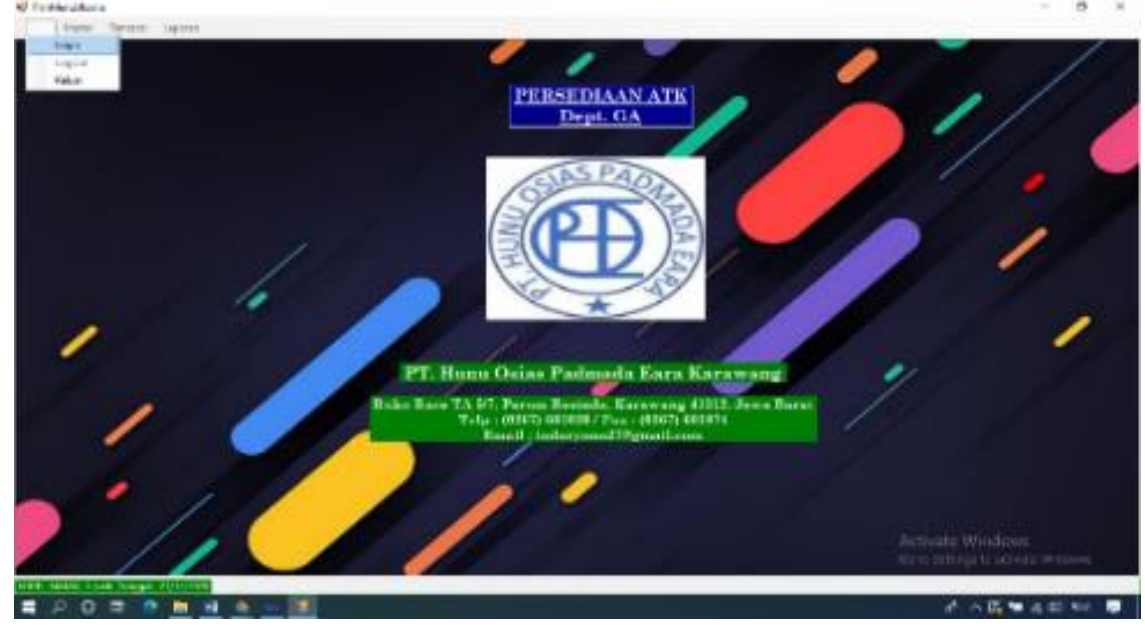

Gambar 9. Tampilan Menu Utama

\subsubsection{Form Login}

Whinien

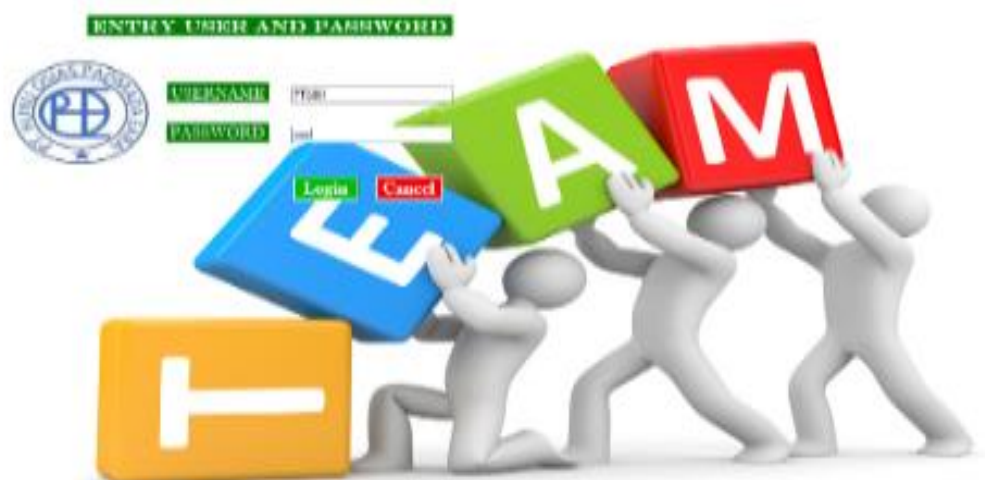

Gambar 10. Tampilan Halaman Login

\subsubsection{Form Master Data Admin}

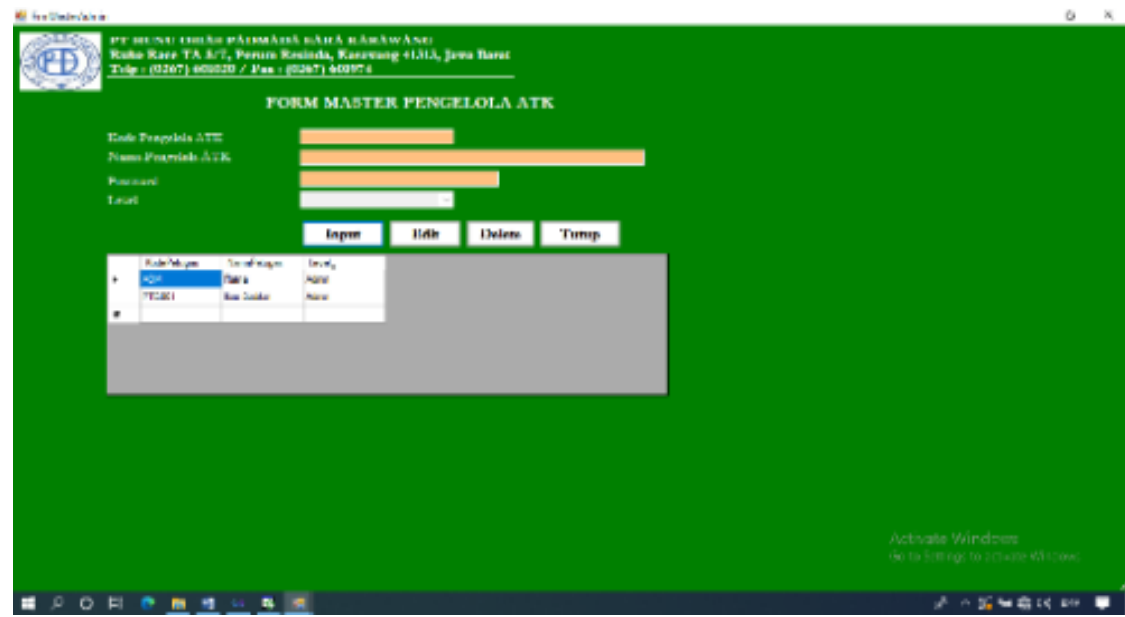

Gambar 11. Tampilan Form Master Pengelola ATK 
4.2.4. Form Master Data Karyawan

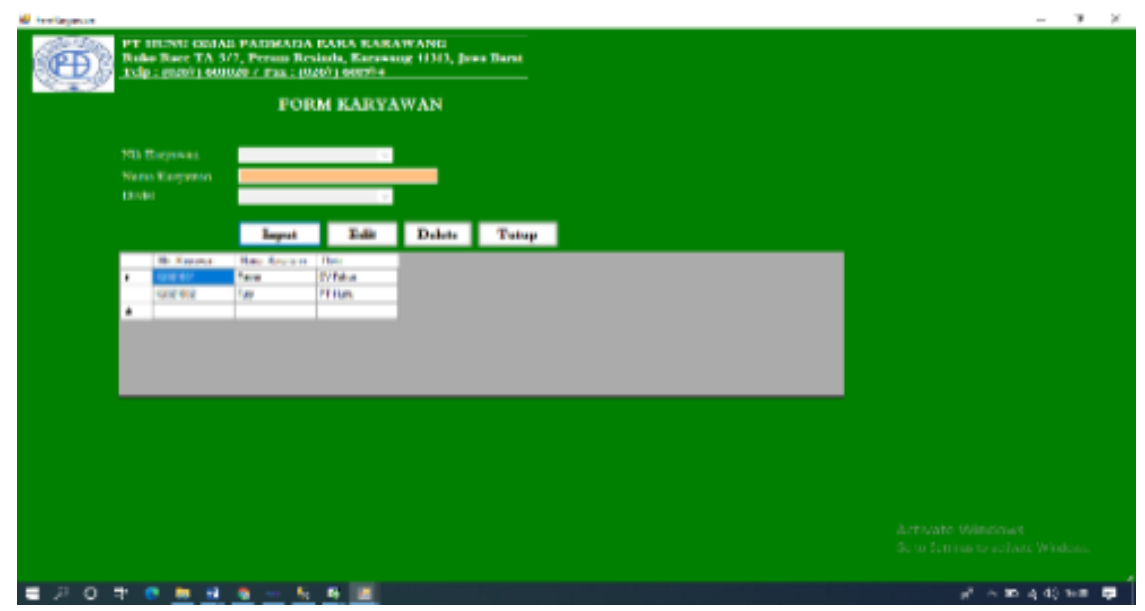

Gambar 12. Tampilan Form Master Karyawan

\subsubsection{Form Master Data ATK}

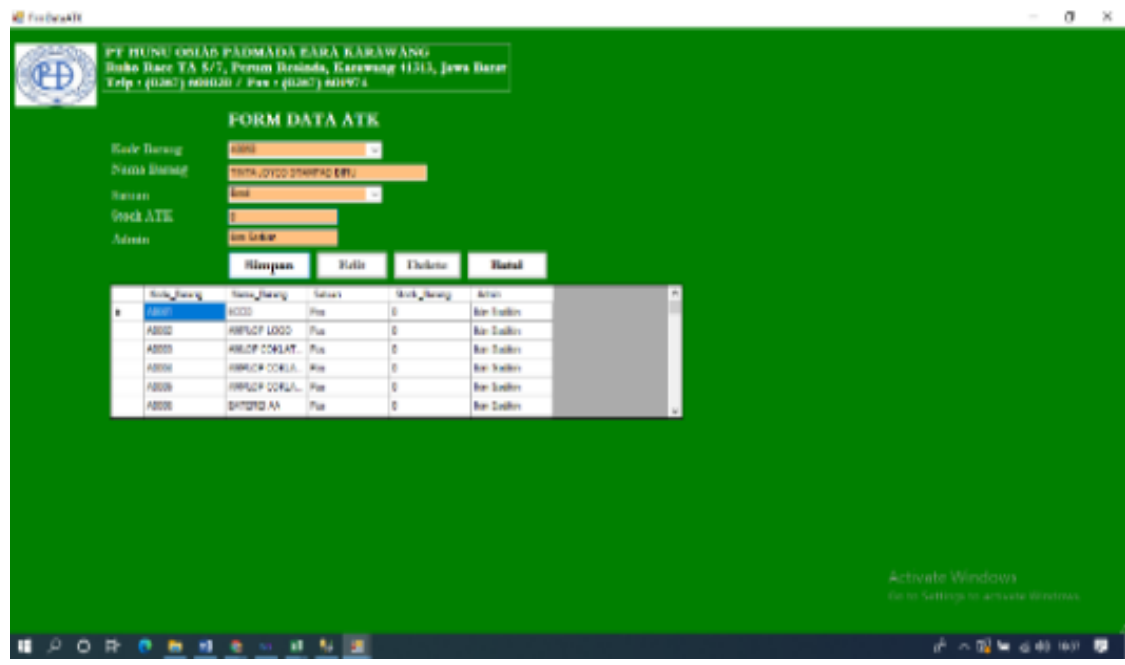

Gambar 13. Tampilan Form Master Data ATK

\subsubsection{Form ATK Masuk}

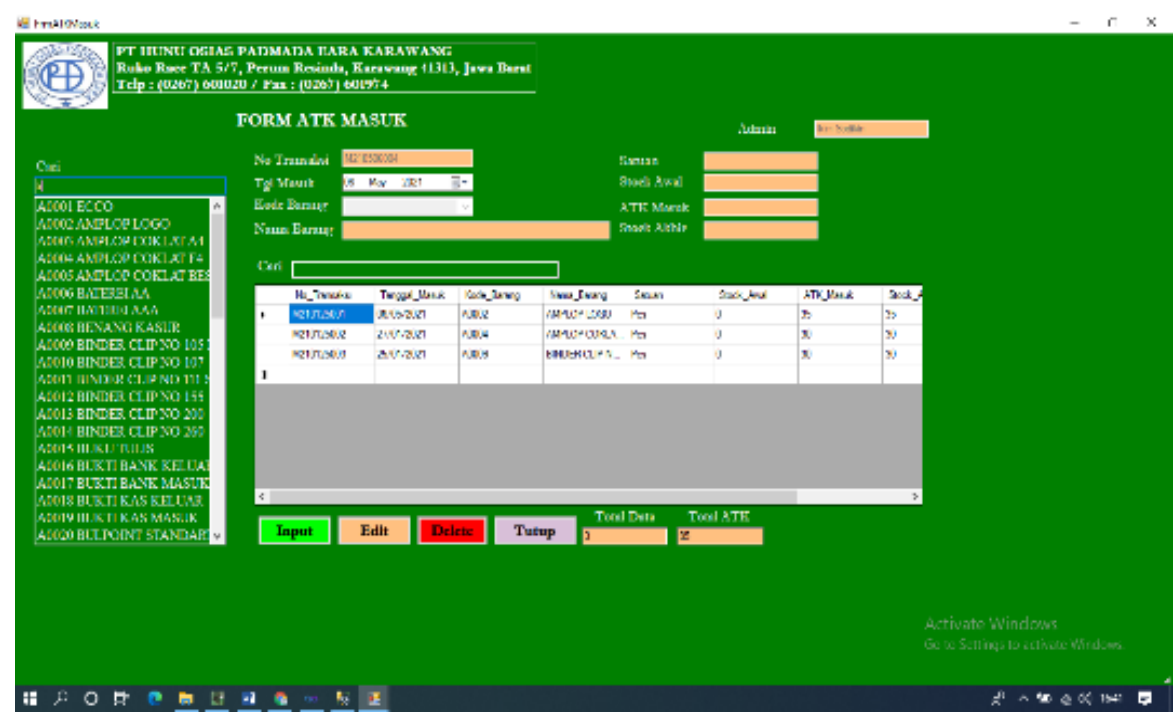

Gambar 14. Tampilan Form ATK Masuk 


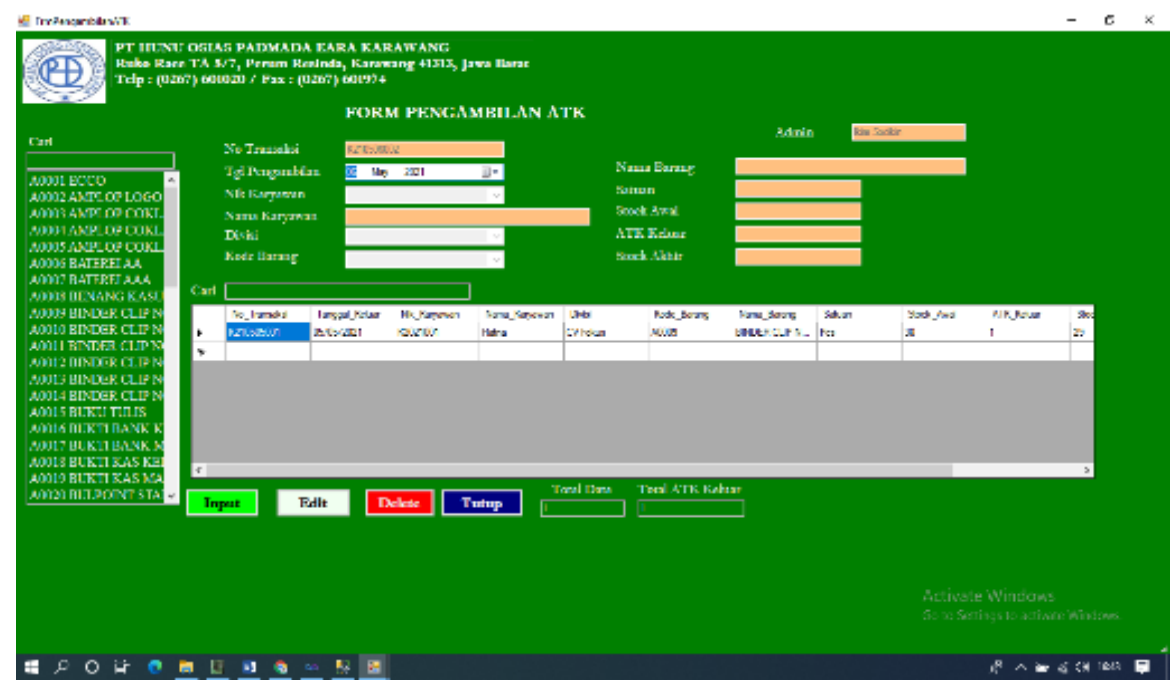

Gambar 15. Tampilan Form ATK Keluar

\subsubsection{Form Laporan Data Master}

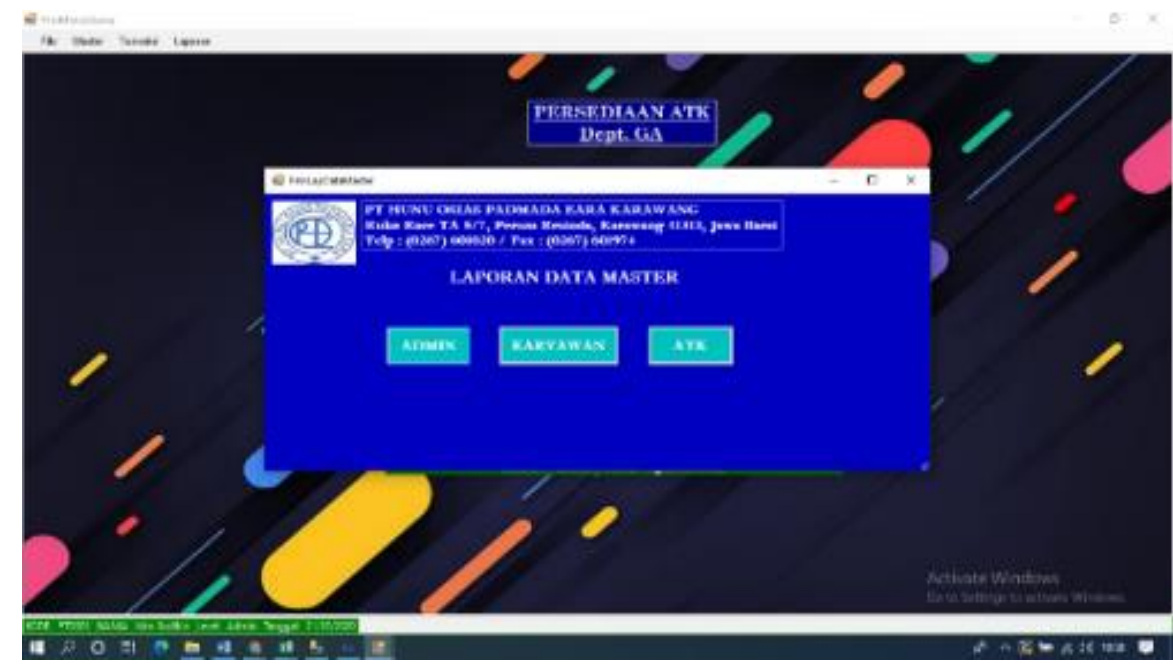

Gambar 16. Tampilan Form Laporan Data Master

\subsubsection{Form Laporan ATK Masuk}

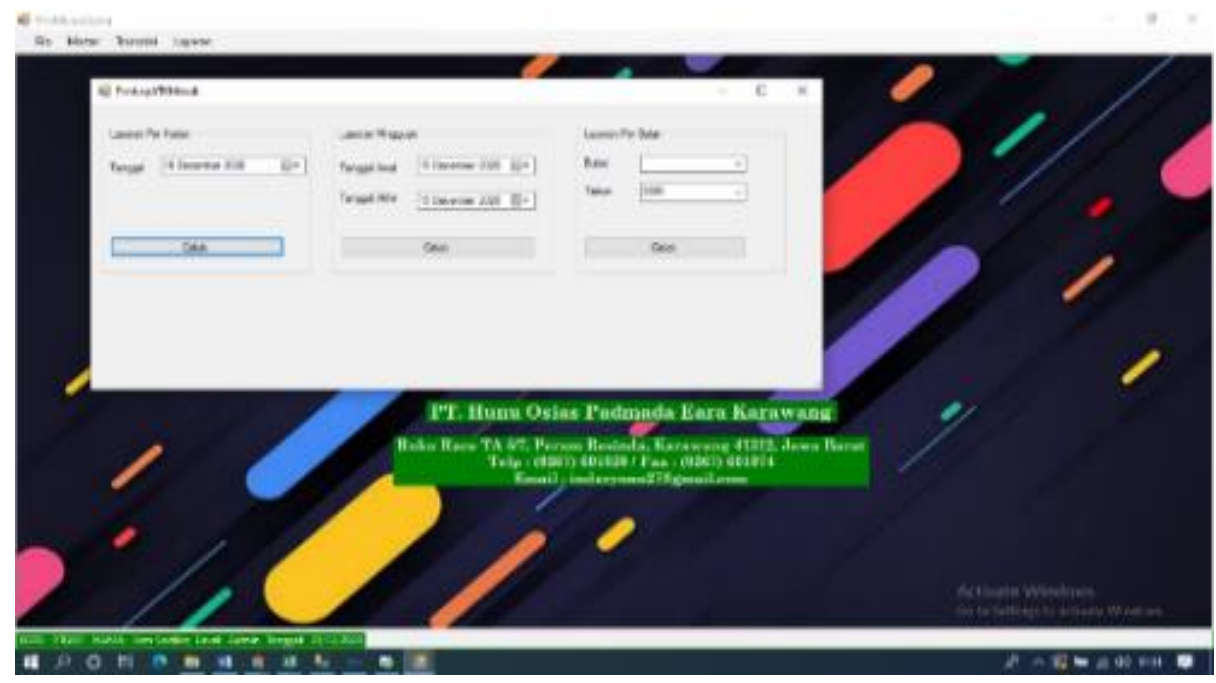

Gambar 17. Tampilan Form Data ATK Masuk 


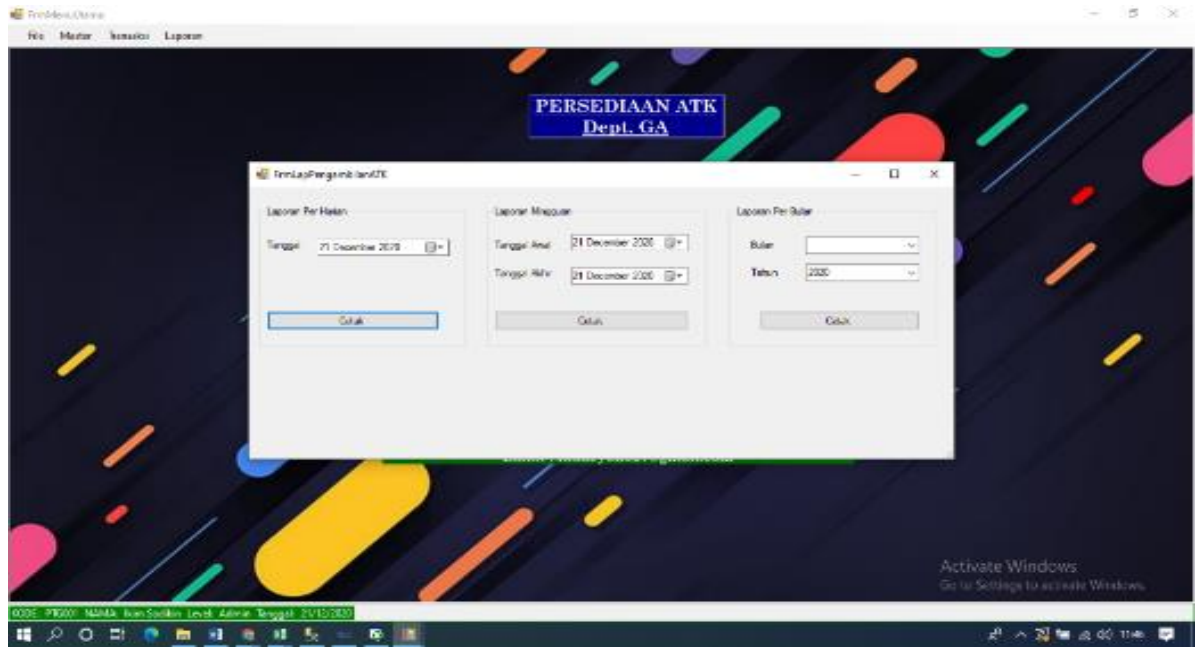

Gambar 18. Tampilan Form Data ATK Keluar

\section{3. $\quad$ Code Testing (Black Box Testing)}

Black-Box Testing yaitu menguji perangkat lunak dari segi spesifikasi fungsional tanpa menguji desain dan kode program. Pengujian ini dimaksudkan untuk mengetahui apakah fungsi-fungsi, masukan dan keluaran dari perangkat lunak telah sesuai dengan spesifikasi yang dibutuhkan [14]. Berikut ini adalah hasil pengujian aplikasi pengelolaan persediaan ATK menggunakan metode Black Box Testing.

Tabel 1. Black Box Testing

\begin{tabular}{|c|c|c|c|c|}
\hline No. & Fungsi yang diuji & Cara Pengujian & Hasil yang diharapkan & $\begin{array}{c}\text { Hasil } \\
\text { Pengujian }\end{array}$ \\
\hline 1. & Form Menu Utama & $\begin{array}{l}\text { Form ini menampilkan halaman } \\
\text { utama dengan pilihan menu. } \\
\text { Untuk mengakses aplikasi maka } \\
\text { user/admin melakukan login } \\
\text { untuk membuka akses menu yang } \\
\text { terkunci. }\end{array}$ & $\begin{array}{l}\text { Menu pada Form menu utama } \\
\text { pada posisi terkunci dan akan } \\
\text { dapat diakses jika user/admin } \\
\text { melakukan login. Data login akan } \\
\text { ditampilkan pada tampilan form } \\
\text { menu utama yaitu kode, nama } \\
\text { admin/user, level dan tanggal } \\
\text { akses. }\end{array}$ & $\mathrm{Ok}$ \\
\hline 2. & Form Login & $\begin{array}{l}\text { Form ini menampilkan halaman } \\
\text { Login untuk masuk sebagai } \\
\text { admin/user. }\end{array}$ & $\begin{array}{l}\text { Setelah login, menu pada form } \\
\text { menu utama akan terbuka dan } \\
\text { dapat diakses. }\end{array}$ & Ok \\
\hline 3. & $\begin{array}{l}\text { Form Master Data } \\
\text { Admin }\end{array}$ & Memilih Sub menu Data Admin & $\begin{array}{l}\text { Menampilkan Form Data Admin, } \\
\text { mengisi, menyimpan, mengedit, } \\
\text { menghapus, dan keluar }\end{array}$ & Ok \\
\hline 4. & $\begin{array}{l}\text { Form } \quad \text { Data } \\
\text { Karyawan }\end{array}$ & $\begin{array}{l}\text { Memilih Sub menu Data } \\
\text { Karyawan }\end{array}$ & $\begin{array}{l}\text { Menampilkan Form Data } \\
\text { Karyawan, mengisi, menyimpan, } \\
\text { mengedit, menghapus, dan keluar. }\end{array}$ & Ok \\
\hline 5. & Form Data ATK & Memilih Sub menu Data ATK & $\begin{array}{l}\text { Menampilkan Form Data ATK, } \\
\text { mengisi, menyimpan, mengedit, } \\
\text { menghapus, dan keluar. }\end{array}$ & Ok \\
\hline 6. & Form ATK Masuk & Memilih Sub menu ATK Masuk & $\begin{array}{l}\text { Menampilkan Form ATK Masuk, } \\
\text { mengisi, menyimpan, mengedit, } \\
\text { menghapus, keluar, melakukan } \\
\text { pencarian data, dan perhitungan } \\
\text { update stock secara otomatis. }\end{array}$ & Ok \\
\hline 7. & Form ATK Keluar & Memilih Sub menu ATK Keluar & $\begin{array}{l}\text { Menampilkan Form ATK Keluar, } \\
\text { mengisi, menyimpan, mengedit, } \\
\text { menghapus, keluar, melakukan }\end{array}$ & Ok \\
\hline
\end{tabular}




\begin{tabular}{|c|c|c|c|c|}
\hline No. & Fungsi yang diuji & Cara Pengujian & Hasil yang diharapkan & $\begin{array}{c}\text { Hasil } \\
\text { Pengujian }\end{array}$ \\
\hline & & & $\begin{array}{l}\text { pencarian data, dan perhitungan } \\
\text { update stock secara otomatis. }\end{array}$ & \\
\hline 8. & $\begin{array}{l}\text { Form Laporan Data } \\
\text { Master }\end{array}$ & $\begin{array}{l}\text { Memilih Sub menu Laporan Data } \\
\text { Master }\end{array}$ & $\begin{array}{l}\text { Menampilkan Sub menu Master } \\
\text { data admin, data karyawan, dan } \\
\text { data ATK }\end{array}$ & Ok \\
\hline 9. & $\begin{array}{l}\text { Form Laporan Data } \\
\text { Master Admin }\end{array}$ & $\begin{array}{l}\text { Memilih Sub menu Laporan Data } \\
\text { Master Admin }\end{array}$ & $\begin{array}{l}\text { Menampilkan form laporan data } \\
\text { master admin yang mengakses } \\
\text { sistem dan cetak. }\end{array}$ & Ok \\
\hline 10. & $\begin{array}{l}\text { Form Laporan Data } \\
\text { Master Karyawan }\end{array}$ & $\begin{array}{l}\text { Memilih Sub menu Laporan Data } \\
\text { Master Karyawan }\end{array}$ & \begin{tabular}{llr}
\multicolumn{3}{l}{ Menampilkan form laporan data } \\
master & Karyawan & yang \\
melakukan & pengambilan & ATK \\
dan cetak. & &
\end{tabular} & Ok \\
\hline 11. & $\begin{array}{l}\text { Form Laporan Data } \\
\text { ATK }\end{array}$ & $\begin{array}{l}\text { Memilih Sub menu Laporan Data } \\
\text { ATK }\end{array}$ & $\begin{array}{l}\text { Menampilkan form laporan Data } \\
\text { ATK yaitu kode barang, nama } \\
\text { barang, stok barang, dan cetak. }\end{array}$ & Ok \\
\hline 12. & $\begin{array}{l}\text { Form Laporan ATK } \\
\text { Masuk }\end{array}$ & $\begin{array}{l}\text { Memilih Sub menu Laporan ATK } \\
\text { Masuk }\end{array}$ & $\begin{array}{l}\text { Menampilkan Sub menu Laporan } \\
\text { ATK Masuk Harian, mingguan, } \\
\text { dan bulanan. }\end{array}$ & Ok \\
\hline 13. & $\begin{array}{l}\text { Form Laporan ATK } \\
\text { Masuk Harian. }\end{array}$ & $\begin{array}{l}\text { Memilih Sub menu Laporan ATK } \\
\text { Masuk Harian. }\end{array}$ & $\begin{array}{l}\text { Menampilkan form laporan ATK } \\
\text { Masuk Harian berdasarkan } \\
\text { tanggal dan cetak. }\end{array}$ & Ok \\
\hline 14. & $\begin{array}{l}\text { Form Laporan ATK } \\
\text { Masuk Mingguan. }\end{array}$ & $\begin{array}{l}\text { Memilih Sub menu Laporan ATK } \\
\text { Masuk Mingguan. }\end{array}$ & $\begin{array}{l}\text { Menampilkan form laporan ATK } \\
\text { Masuk per minggu berdasarkan } \\
\text { tanggal mulai dan tanggal akhir } \\
\text { dan cetak. }\end{array}$ & Ok \\
\hline 15. & $\begin{array}{l}\text { Form Laporan ATK } \\
\text { Masuk Bulanan. }\end{array}$ & Laporan ATK Masuk Bulanan. & $\begin{array}{l}\text { Menampilkan form laporan ATK } \\
\text { Masuk per Bulan berdasarkan } \\
\text { bulan tertentu dan cetak. }\end{array}$ & Ok \\
\hline 16. & $\begin{array}{l}\text { Form Laporan ATK } \\
\text { Keluar }\end{array}$ & $\begin{array}{l}\text { Memilih Sub menu Laporan ATK } \\
\text { Keluar }\end{array}$ & $\begin{array}{l}\text { Menampilkan Sub menu Laporan } \\
\text { ATK Keluar Harian, mingguan, } \\
\text { dan bulanan. }\end{array}$ & Ok \\
\hline 17. & $\begin{array}{l}\text { Form Laporan ATK } \\
\text { Keluar Harian }\end{array}$ & Laporan ATK Keluar Harian & $\begin{array}{l}\text { Menampilkan form laporan ATK } \\
\text { Keluar Harian berdasarkan } \\
\text { tanggal dan cetak. }\end{array}$ & Ok \\
\hline 18. & $\begin{array}{l}\text { Form Laporan ATK } \\
\text { Keluar Mingguan }\end{array}$ & $\begin{array}{l}\text { Memilih Sub menu Laporan ATK } \\
\text { Keluar Mingguan }\end{array}$ & $\begin{array}{l}\text { Menampilkan form laporan ATK } \\
\text { Keluar per minggu berdasarkan } \\
\text { tanggal mulai dan tanggal akhir } \\
\text { dan cetak. }\end{array}$ & Ok \\
\hline 19. & $\begin{array}{l}\text { Form Laporan ATK } \\
\text { Keluar Bulanan }\end{array}$ & Laporan ATK Keluar Bulanan & $\begin{array}{l}\text { Menampilkan form laporan ATK } \\
\text { Keluar per Bulan berdasarkan } \\
\text { bulan tertentu. }\end{array}$ & Ok \\
\hline
\end{tabular}

\section{Kesimpulan dan Saran}

\subsection{Kesimpulan}

Pengelolaan persediaan ATK pada di PT. Hunu Osias Padmada Eara Karawang masih manual yaitu dengan menggunakan Microsoft Excel yang dinilai masih kurang efektif karena Microsoft excel tidak memiliki Database, dan memungkinkan data hilang atau rusak, sehingga menyebabkan sulitnya dalam mengelola data persedian ATK dan pembuatan laporan. Berdasarkan permasalahan tersebut, penulis menrancang sebuah aplikasi pengelolaan persediaan ATK yang dibangun menggunakan Microsoft Visual Basic. Net dan Microsoft SQL Server sebagai databasenya. Hasil implementasi sistem yang telah dilakukan pada PT. PT Hunu Osias Padmada Eara Karawang menujukkan bahwa aplikasi persediaan ATK mampu meningkatkan efektifitas dan efisiensi dalam pengelolaan persediaan ATK dan pembuatan laporan, serta mampu meminimalisir kesalahan yang mungkin terjadi karena kesalahan input dalam pembuatan laporan dan sebagainya.

\subsection{Saran}


Berdasarkan pembahasan dari hasil penelitian yang dilakukan, maka penulis mencoba memberikan saran-saran yang diharapkan dapat berguna bagi pihak perusahaan. Adapun saran-saran yang penulis berikan adalah sebagai berikut :

a. Agar persediaan ATK dapat dikelola dengan baik maka pada kartu stok ATK Dibuatkan kolom untuk nama karyawan yang melakukan permintaan ATK sebagai pertanggungjawaban data nama dan bagian kerjanya.

b. Untuk mengatasi kekurangan kebutuhan ATK sebaiknya setiap bagian membuat perencanaan kebutuhan ATK setiap bulannya.

c. Penulis mengusulkan perancangan pengelolaan persediaan ATK menggunakan Vb.net, dengan metode FIFO yang merupakan pengembangan dari kegiatan pengelolaan ATK yang dilakukan secara manual.

d. Sistem informasi pengelolaan ATK ini diharapkan dapat membantu dan mempercepat proses pembuatan laporan persediaan ATK, sehingga dapat dijadikan pengambilan keputusan oleh manajemen, Serta memberikan bukti-bukti yang akurat baik itu penerimaan maupun pemakaian ATK.

\section{References}

[1] M. I. Fitrianda, "Digital Digital Repository Repository Universitas Universitas Jember Jember Digital Digital Repository Repository Universitas Universitas Jember," 2013.

[2] M. Fadly, D. Suhendro, and A. Syahputra, "Perancangan Aplikasi Persediaan Barang dan Bahan Makanan Menggunakan Metode FIFO pada KFC Pematangsiantar," J. Ilm. Media Sisfo, vol. 13, no. 1, 2019, doi: 10.33998/mediasisfo.2019.13.1.527.

[3] E. R. Harahap, G. Lumbantoruan, and J. Jamaluddin, “Aplikasi Persediaan Barang Menggunakan Metode FIFO pada CV Bandung Jaya," Methoda, vol. 9, no. 2, pp. 74-78, 2019.

[4] E. Tohidi and Kaslani, "Sistem Informasi Pelaporan Laba Rugi Pendapatan Jasa Menggunakan Metode Waterfall Untuk Mempercepat Proses Perhitungan," J. Komput. Akunt., vol. 15, no. 1, 2019, doi: 10.14894/faruawpsj.17.12_1173_2.

[5] metode penelitian Nursalam, 2016 and A. . Fallis, "PROSEDUR AKUNTANSI PENGADAAN ALAT TULIS KANTOR PADA KANTOR DINAS PEMUDA DAN OLAHRAGA KABUPATEN JEMBER," PROSEDUR Akunt. PENGADAAN ALAT TULIS Kant. PADA Kant. DINAS PEMUDA DAN OLAHRAGA KABUPATEN JEMBER, vol. 53, no. 9, pp. 1689-1699, 2013.

[6] B. Boedijono, G. Wicaksono, Y. Puspita, S. C. Bidhari, N. D. Kusumaningrum, and V. Asmandani, "Efektifitas Pengelolaan Dana Desa Untuk Pembangunan Dan Pemberdayaan Masyarakat Desa Di Kabupaten Bondowoso," J. Ris. Manaj. dan Bisnis Fak. Ekon. UNIAT, vol. 4, no. 1, pp. 9-20, 2019, doi: 10.36226/jrmb.v4i1.237.

[7] S. Hartono, "Membangun Sistem Informasi Persediaan Perlengkapan Kantor Pada Pt Haleyora Power," vol. 3, pp. 256-263, 2019.

[8] A. Muka and M. Persediaan, "Bab 5 pengelolaan persediaan."

[9] Yessi Erika Wati, "Pengelolaan barang habis pakai (alat tulis kantor) pada dinas perindustrian, perdagangan, koperasi dan umkm Kabupaten Karanganyar," Univsersitas Sebelas Maret, 2016.

[10] A. Setiajati, I. Cholissodin, and A. W. Widodo, "Optimasi Pembagian Barang Alat Tulis Kantor Menggunakan Algoritma Genetika," Pengemb. Teknol. Inf. dan Ilmu Komput., vol. 2, no. 3, pp. 1248-1256, 2018.

[11] metode penelitian Nursalam, 2016 and A. . Fallis, "Pengelolaan Barang Habis Pakai (Alat Tulis Kantor) Pada Dinas Komunikasi Dan Informatika Kabupaten Nias Selatan,” J. Chem. Inf. Model., vol. 53, no. 9, pp. 16891699, 2013.

[12] M. R. Julianti, M. I. Dzulhaq, and A. Subroto, "Sistem Informasi Pendataan Alat Tulis Kantor Berbasis Web pada PT Astari Niagara Internasional," vol. 9, no. 2, 2019.

[13] P. A. Ashari, B. Hariadi, and Sulistiowati, "Rancang Bangun Aplikasi Analisis Kepuasan Pengunjung pada Badan Perpustakaan dan Kearsipan Provinsi Jawa Timur," JSIKA, vol. 5, no. 11, 2016.

[14] B. Iskandar and A. U. Hamdani, "Jasa Pengiriman Barang Studi Kasus : PT. XYZ," STMIK AMIKOM Yogyakarta, vol. 1, no. 2, pp. 67-72, 2017. 